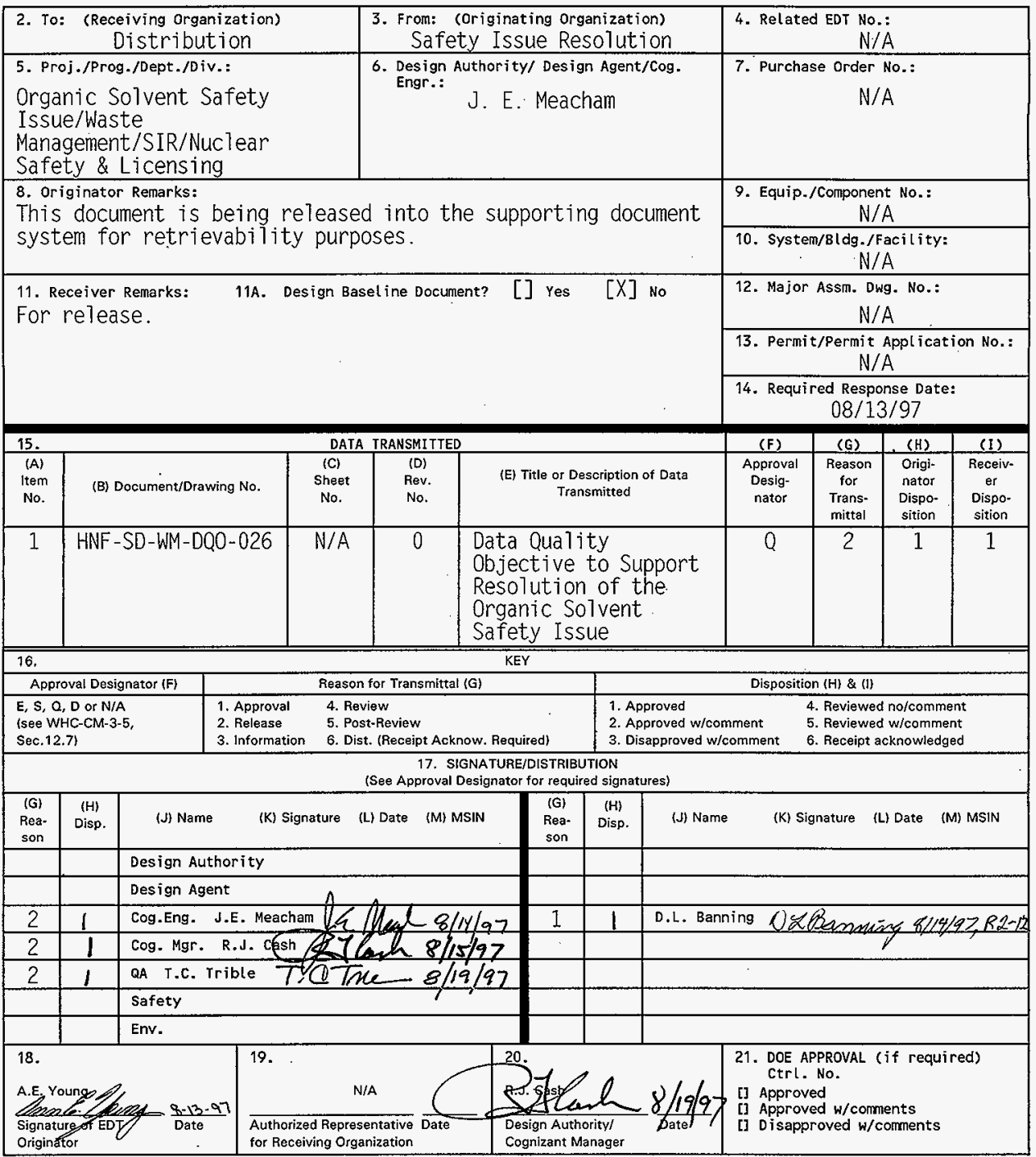




\section{Data Quality Objective to Support Resolution of the Organic Solvent Safety Issue}

J. E. Meacham

DE\&S Hanford. Inc., Richland, WA 99352

U.S. Department of Energy Contract DE-AC06-87RL10930

$\begin{array}{lll}\text { EDT/ECN: } & \text { EDT-617688 } & \text { UC: } 2070 \\ \text { Org Code: } & 2 \mathrm{~N} 160 & \text { Charge Code: }{ }^{N 4 G 2 B} \\ \text { B\&R Code: } & \text { EW } 3120074 & \text { Total Pages: } 30 \\ 28 & \mu_{8 / 19} / 97\end{array}$

Key Words: Data Quality Objective, DQ0, Resolution, Organic, Solvent, Safety, Issue

Abstract: N/A

TRADEMARK DISCLAIMER. Reference herein to any specific comercial product, process, or service by trade name, trademark, manufacturer, or otherwise, does not necessarily constitute or imply its endorsement, recormendation, or favoring by the United States Government or any agency thereof or its contractors or subcontractors.

Printed in the United States of America. To obtain copies of this document, contact: WHC/BCS Document Control Services, P.O. Box 1970, Mailstop H6-08, Richland WA 99352, Phone (509) 372-2420; Fax (509) 376-4989.
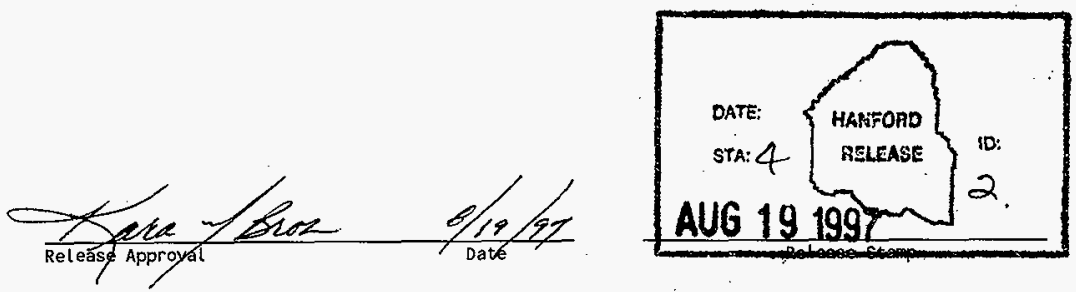

Approved for Public Release 


\title{
Data Quality Objective to Support Resolution of the Organic Solvent Safety Issue
}

\author{
J. E. Meacham \\ DE\&S Hanford, Inc. \\ D. L. Banning \\ Lockheed Martin Hanford Corporation
}

M. R. Allen

L. D. Muhlestein

ARES Corporation

Date Published

August 1997

Prepared for the U.S. Department of Energy

Assistant Secretary for Environmental Management 


\section{TABLE OF CONTENTS}

1.0 INTRODUCTION $\ldots \ldots \ldots \ldots \ldots \ldots \ldots \ldots \ldots \ldots \ldots \ldots \ldots \ldots \ldots \ldots \ldots \ldots$

2.0 STATEMENT OF THE PROBLEM $\ldots \ldots \ldots \ldots \ldots \ldots \ldots \ldots \ldots \ldots \ldots \ldots \ldots \ldots$

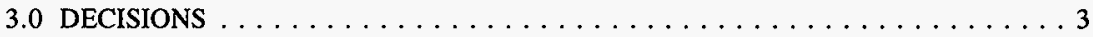

3.1 ORGANIC SOLVENT SAFETY ISSUE $\ldots \ldots \ldots \ldots \ldots \ldots \ldots$

3.2 DECISIONS FOR ORGANIC SOLVENTS $\ldots \ldots \ldots \ldots \ldots \ldots$

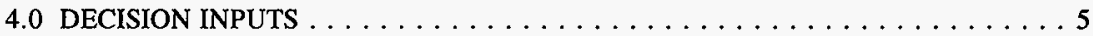

4.1 IDENTIFICATION OF DECISION INPUTS $\ldots \ldots \ldots \ldots \ldots \ldots$

4.2 INFORMATION SOURCES FOR DECISION INPUTS $\ldots \ldots \ldots \ldots \ldots 5$

5.0 STUDY BOUNDARIES $\ldots \ldots \ldots \ldots \ldots \ldots \ldots \ldots \ldots \ldots$

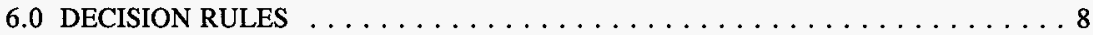

6.1 DECISION RULE FOR ORGANIC SOLVENTS $\ldots \ldots \ldots \ldots \ldots$

6.2 BASES FOR DECISION LIMITS $\ldots \ldots \ldots \ldots \ldots \ldots$

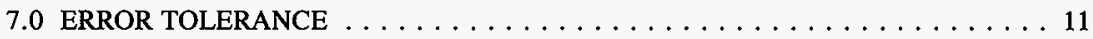

8.0 DATA OPTIMIZATION $\ldots \ldots \ldots \ldots \ldots \ldots \ldots \ldots \ldots \ldots \ldots \ldots \ldots$

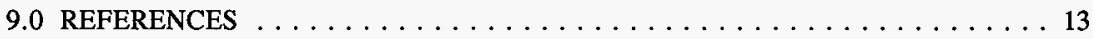
APPENDIX

TECHNICAL BASES FOR SURFACE AREA OF SOLVENT POOL . . . . . A A - 1 


\section{FIGURES}

3-1 Strategy to Resolve the Safety Issue of Waste Tanks That

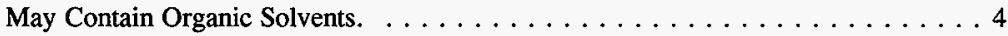

6-1 Criterion for the Waste Tank Organic Vapor Concentration as a Function of the Headspace Temperature $\ldots \ldots \ldots \ldots \ldots \ldots$

\section{TABLES}

4-1 Decision Inputs for Organic Solvent Decisions. $\ldots \ldots \ldots \ldots \ldots \ldots$

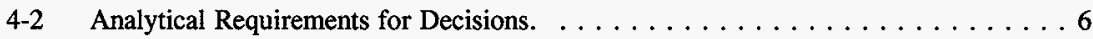

\section{LIST OF TERMS}

DQO data quality objective

DOE U.S. Department of Energy

DST double-shell tank

EPA U.S. Environmental Protection Agency

HASQAP Hanford Analytical Service Quality Assurance Plan

HEPA high-efficiency particulate air (filter)

ISVS in situ vapor sampling

NPH normal petroleum hydrocarbon

TSAP tank sampling analysis plan

SST single-shell tank

TBP tributyl phosphate

TCP tank characterization plan

TNMOCs total non-methane organic compounds

TWRS Tank Waste Remediation System

VSS vapor sampling system 


\subsection{INTRODUCTION}

The Tank Waste Remediation System (TWRS) has adopted a data quality objective (DQO) process to define informational needs required to address waste tank safety issues. This document, the Organic Solvent DQO, provides a process to resolve the Organic Solvent Safety Issue. Organic solvents in the presence of air (a source of oxidizer) in a waste tank headspace can combust when heated to the flash point of the solvent. Separable phase organic liquids can form a combustible situation by being present as a pool on the waste surface, or by collecting in sufficient concentration entrained in the waste solids to form a combustible mixture at the waste surface by capillary or wicking behavior. Organic solvent combustion would result in an increase in pressure and temperature of the gas in the waste tank headspace. A significant pressure increase could result in the release of radionuclides and toxic materials to the environment.

The Organic Solvent DQO is based on several technical documents, summarized and referenced throughout, that provide the technical bases for threshold values (decision limits) used to develop decision rules that address the problem statement. Likewise, this DQO supports characterization documents, such as the tank sampling analysis plan (TSAP) and tank characterization plan (TCP). The threshold values are based upon approved technical documents. Any changes to these technical documents will be reflected in subsequent changes to this DQO.

This DQO applies to static organic waste as presently stored in single-shell tanks (SSTs) and double-shell tanks (DSTs). Waste undergoing retrieval, pretreatment, and processing are outside the scope of this DQO. 


\subsection{STATEMENT OF THE PROBLEM}

During the defense mission at the Hanford Site, organic solvents were used in fuel reprocessing, metal recovery operations, and waste management operations. Organic solvents when mixed with air (an oxidizer) can combust if subjected to a sufficient ignition source.

The problem addressed by the Organic Solvent DQO is the following:

What is the risk from the organic solvent hazard?

This DQO deals specifically with the Organic Solvent Safety Issue and defines the data required to resolve this safety issue. A separate DQO addresses the Organic Complexant Safety Issue (Turner et al. 1995). 


\subsection{DECISIONS}

This section discusses the safety issue associated with wastes that contain organic solvents. The decisions to be addressed relative to the Organic Solvent Safety Issue are also discussed.

\subsection{ORGANIC SOLVENT SAFETY ISSUE}

Organic solvents when mixed with an oxidizing material could combust if subjected to a sufficient ignition source. The resulting organic solvent combustion would cause an increase in pressure and temperature of the gas in the tank headspace. A significant pressure increase could result in the release of radionuclides and toxic materials to the environment. If the quantity of organic solvent in a tank is small, then that tank does not contribute to the facilitywide organic solvent hazard (Cowley and Postma 1996). Furthermore, if few tanks contain a significant amount of organic solvent, then the facility-wide risk of an organic solvent combustion event falls within risk evaluation guidelines (Cowley and Postma 1996).

This DQO is a facility wide DQO and applies to all tanks.

\subsection{DECISIONS FOR ORGANIC SOLVENTS}

The decision statements identify the questions to be resolved in order to solve the Problem Statement (Section 2.0) and the Organic Solvent Safety Issue.

The decision to be resolved is the following:

Is the risk of an organic solvent combustion event low (i.e., within the risk evaluation guidelines)?

Figure 3-1 provides the decision logic relative to the above decision statement. 
Figure 3-1. Strategy to Resolve the Safety Issue of Waste Tanks That May Contain Organic Solvents.

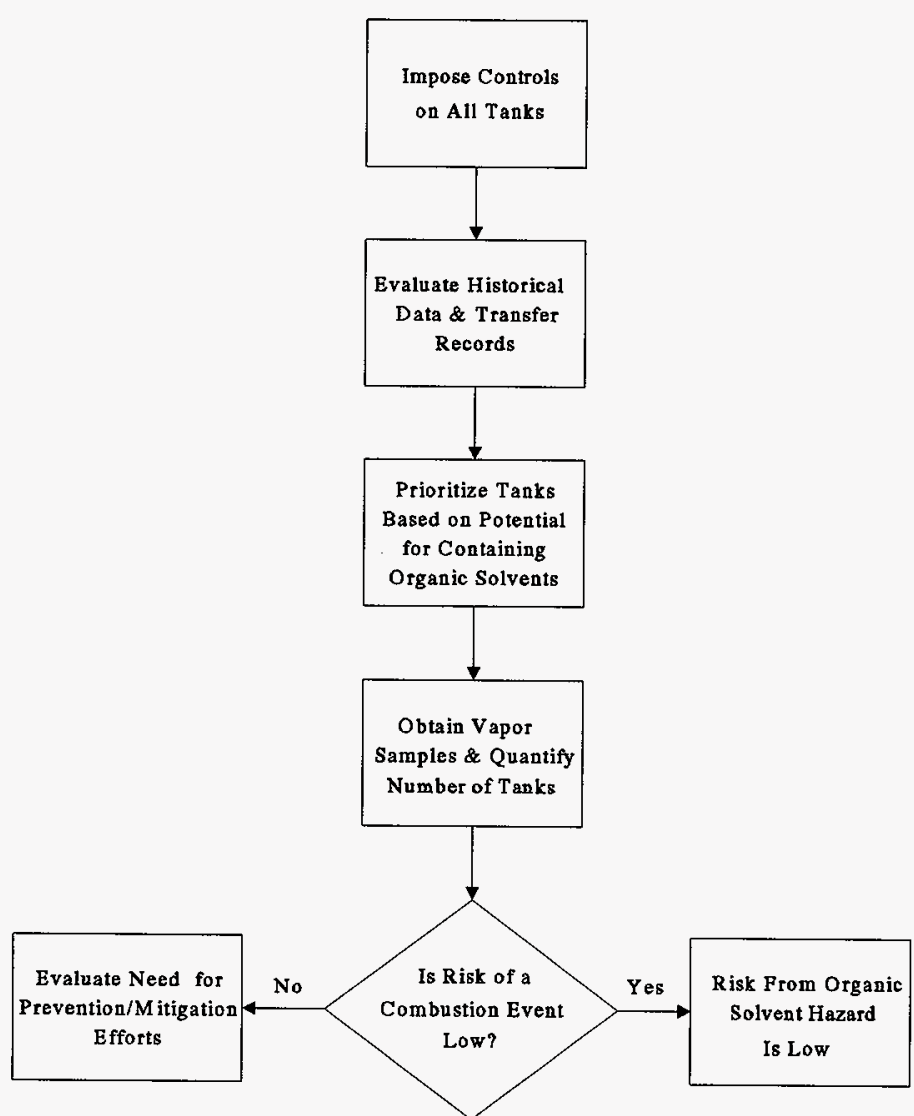




\subsection{DECISION INPUTS}

This section identifies the decision inputs to address the decision statement and the sources of information for those inputs.

\subsection{IDENTIFICATION OF DECISION INPUTS}

Decision inputs may consist of any information or data that can help address the decision questions. The decision inputs required to make the decisions are summarized in Table 4-1. The decision input is listed along with the reason it is needed.

Table 41. Decision Inputs for Organic Solvent Decisions.

\begin{tabular}{|l|l|l|}
\hline Decision & Decision Input & Reason for Decision Input \\
\hline $\begin{array}{l}\text { Is the risk of an organic } \\
\text { solvent combustion event } \\
\text { low (i.e., within the risk } \\
\text { evaluation guidelines)? }\end{array}$ & $\begin{array}{l}\text { a. Organic solvent } \\
\text { combustion model. }\end{array}$ & $\begin{array}{l}\text { Headspace sample results are } \\
\text { combined with the organic } \\
\text { solvent vapor model and } \\
\text { combustion model to } \\
\text { determine if the risk of an } \\
\text { organic solvent combustion } \\
\text { event is low. }\end{array}$ \\
\cline { 2 - 3 } & $\begin{array}{l}\text { brganic solvent vapor } \\
\text { sample model. }\end{array}$ & $\begin{array}{l}\text { Tank headspace sample } \\
\text { results. }\end{array}$
\end{tabular}

\subsection{INFORMATION SOURCES FOR DECISION INPUTS}

The organic solvent combustion model is detailed in Cowley and Postma (1996) and Cowley et al. (1997), and these references are the information source for this decision input. The solvent combustion model provides the technical basis for determining the minimum pool size that is considered a hazard. A summary of the solvent combustion model is provided in the Appendix.

The organic solvent vapor model also described in Cowley et al. (1997) and Huckaby et al. (1997), and these references are the information source for this decision input. The organic solvent vapor model provides the technical basis for translating tank headspace sample results into an equivalent organic solvent pool size. The model requires a headspace temperature measurement and vapor sample (see Table 4-2). A summary of the organic solvent vapor model is also provided in the Appendix.

The tank headspace sample results are the measured concentration of total non-methane organic compounds (TNMOCs). The TNOMCs measurements include semivolatile species 
and volatile species and results in an overestimate of the semivolatile organic compounds, which are the potentially hazardous components. The TNMOCs analysis is used as a screen because it is more cost effective than the speciation of the semivolatiles. If the TNMOC exceeds the criterion (see Figure 6.1), the mass fraction concentration of semivolatile species (i.e., $n$-decane and the compounds that elute after $\mathrm{n}$-decane in a gas chromatogram) will be measured. The methodology selected to collect the sample [e.g., vapor sampling system (VSS) or in situ vapor sampling (ISVS)] must meet the uncertainty requirements specified in Section 7.0 (Error Tolerance). The method for analyzing the vapor samples taken from the waste tank headspace must give results for TNMOCs and/or mass fraction concentration of semivolatile species. The results must also meet the uncertainty requirements specified in Section 7.0.

Table 4-2. Analytical Requirements for Decisions.

\begin{tabular}{|c|l|c|}
\hline Safety Issue & \multicolumn{1}{|c|}{ Analyte Measured } & \multicolumn{1}{c|}{ Sample Location } \\
\hline \multirow{3}{*}{$\begin{array}{l}\text { Organic Solvent } \\
\text { Combustion }\end{array}$} & $\begin{array}{l}\text { First measure TNMOCs concentration, if } \\
\text { exceeds criteria then measure mass fraction } \\
\text { concentration of semivolatiles. }\end{array}$ & Waste tank headspace \\
\cline { 2 - 4 } & Waste tank headspace temperature $\left({ }^{\circ} \mathrm{C}\right)$ & Waste tank headspace \\
\hline
\end{tabular}




\subsection{STUDY BOUNDARIES}

The definition of the study boundaries include:

- Spatial boundaries that define the physical area to be studied and the location where the samples should be taken.

- Temporal boundaries that describe the time frame for the study and when samples should be taken.

The spatial boundary is the Hanford site high-level waste single-shell tanks and double-shell tanks. The sampling boundary is defined as the waste tank under consideration. The location where the sample should be taken is the waste tank headspace. The temporal boundary is defined by the prioritized lists of all tanks to be sampled for organic solvents. Organic solvent waste degrades with time, and organic solvent is no longer disposed to the Hanford Site tanks. Therefore, resampling of the waste tank, at a later date, is not required. 


\subsection{DECISION RULES}

A decision rule has been developed to answer the decision question of Section 3.2 based on the inputs identified in Section 4.0. The decision rule has been developed as an "If...then...; otherwise..." statement that outlines the conditions under which alternative actions will be chosen.

\subsection{DECISION RULE FOR ORGANIC SOLVENTS}

The decision rule is:

If the risk of an organic solvent combustion event is low (i.e., within risk evaluation guidelines), then no additional action is required; otherwise evaluate the need for appropriate preventative or mitigative actions.

Waste tanks are placed on a prioritized sampling list based on historical waste tank data and transfer records that indicate the potential for organic solvents to be present. The waste tank headspace is vapor sampled, and the temperature of the headspace is measured. The TNMOCs concentration is compared to the screening criterion developed from the organic solvent vapor model. If the TNMOCs concentration exceeds the criterion, then the concentration of semivolatiles (i.e., n-decane and all compounds that would subsequently elute in a gas chromatogram) is measured. If the TNMOCs or semivolatiles concentration at the headspace temperature is below the criterion curve shown in Figure 6-1, then the tank does not contain a significant amount of organic solvent (i.e., greater than a $1 \mathrm{~m}^{2}$ pool). The screening criterion shown in Figure 6-1 is applied as a knife edge. That is, the uncertainty is factored into the TNMOCs or semivolatiles measurement, and the $95 \%$ confidence value is compared against the criterion (Huckaby et al. 1997).

If ten or more passively ventilated single-shell tanks contain the equivalent of a $1 \mathrm{~m}^{2}$ pool, then the combustion model predicts that the risk from an organic solvent combustion event might exceed the existing risk evaluation guidelines (Cowley and Postma 1996). If the organic solvent hazard exceeds risk evaluation guidelines, further refinements to the combustion and screening models [see description of planned model improvements in Cowley et al. (1997)] are warranted, and preventative or mitigative actions will be considered. 
Figure 6-1. Criterion for the Waste Tank Organic Vapor Concentration as a Function of the Headspace Temperature.

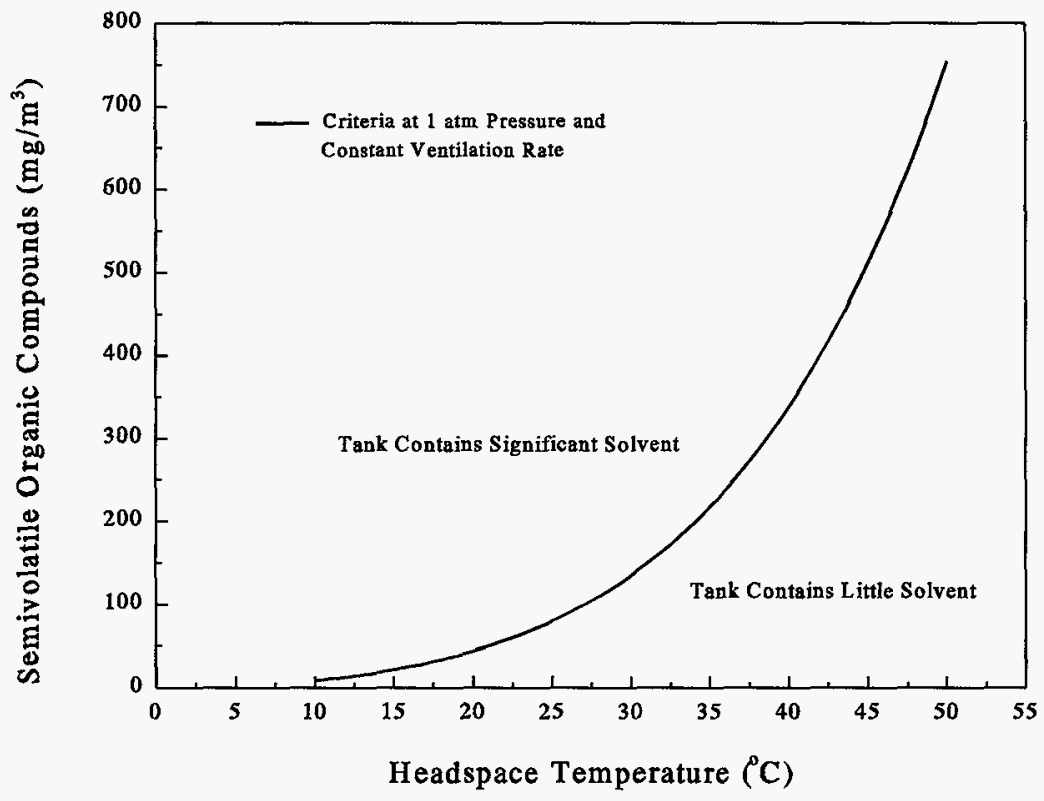

\subsection{BASES FOR DECISION LIMITS}

A solvent vapor transport model was developed by equating the vapor outflow rate in the ventilation air to the pool evaporation rate. In the solvent vapor model, the concentration of solvent vapors in a waste tank headspace is correlated with the organic solvent pool surface area. Important parameters in the model are headspace ventilation rate (for actively or passively ventilated tanks), temperature at the pool surface, mass transfer coefficient for solvent evaporation, volatility of the solvent at a specified temperature, and the concentration of solvent vapors in headspace air. 
An organic solvent combustion model was also developed that relates the quantity of organic solvent and the corresponding surface pool area to the rate of combustion and, to the temperature and pressure increase. The Appendix provides a summary of the solvent vapor model and combustion model. The analysis summarized in the Appendix was based on the following constraints:

- The solvent fire was initiated on a circle 1 foot in diameter.

- The fire spreads radially at a velocity of 10 centimeters per second.

- Vent paths were limited to the U-Tube seal on the high-efficiency particulate air (HEPA) vent riser.

- The duration of the fire was limited by oxygen extinguishment at $13 \%$ oxygen.

- Peak tank pressure was limited to 5 pounds per square inch gauge pressure (psig). (This is less than half the 11 psig limit).

Based on these constraints, the analysis concluded that an organic solvent pool with surface area less than or equal to $1 \mathrm{~m}^{2}$ (headspace concentration below the criterion curve of Figure 6-1) poses a low risk.

As more waste tank vapor sample data are obtained and analyzed, the models and analysis will be refined. Consequently, the criteria presented in the Appendix may also need to be refined. This is particularly true as a better understanding of waste tank ventilation rates is gained. 


\subsection{ERROR TOLERANCE}

Error tolerances for the decisions identified in this report represent a balance between the need for precise analytical resuits and the impact of making an incorrect decision based on the sample results. There is no universal model for determining decision error tolerances; therefore, tolerances are often based on specific assumptions, prior knowledge, and/or expert opinion.

When determining the acceptable probability of making an incorrect decision, the consequences of that decision error must be assessed. It is tempting to ignore statistical uncertainties and state that whenever a tank has a $1 \mathrm{~m}^{2}$ pool of organic solvent, that it will be correctly identified with $100 \%$ confidence. However, statistical uncertainties cannot be ignored. Thus, acceptable probabilities of making decision errors must be specified considering the consequences of those decision errors.

The consequences of not identifying a tank with an organic pool larger than $1 \mathrm{~m}^{2}$ are small because of the large conservatism factored into the criterion. The $1 \mathrm{~m}^{2}$ organic solvent pool fuel criterion was based on a conservative screening assessment, and the actual hazardous pool size is closer to $10 \mathrm{~m}^{2}$ (Cowley and Postma 1996, Cowley et al. 1997). Therefore, it was deemed acceptable to have a $5 \%$ probability of concluding that a tank does not contain a significant amount of solvent, when in fact it does. A tank will be judged to contain little solvent if there is $95 \%$ confidence that a $1 \mathrm{~m}^{2}$ solvent pool does not exist. The solvent screening criterion (shown in Figure 6-1) is applied as a knife edge. That is, the uncertainty is factored into the TNMOC or semivolatile measurement and the $95 \%$ confidence value is compared against the criterion (Cowley et al. 1997).

Potential error sources in screening tanks for organic solvent include (1) variance in ventilation rate, (2) variance in the measured organic vapor concentration (e.g., within tank variations, between tank variations, and analytical error), (3) variance in the estimated saturated vapor concentration, and (4) variance in the mass transfer coefficient (Huckaby et al. 1997, Cowley et al. 1997). The variance associated with the estimated tank ventilation rates, saturated vapor concentrations, and mass transfer coefficients are discussed in Huckaby et al. (1997). The variance in the measured organic vapor concentration is derived from the sampling and analysis data.

Organic vapor measurement errors are small relative to other potential errors (Huckaby et al. 1997), particularly if the measurements are completed according to the appropriate implementing Quality Assurance Plan (Trible and Viswanath 1996). The acceptable uncertainty in the TNMOC measurement for solvent is $\pm 30 \%$ or less for use in solvent screening (Huckaby et al. 1997). The sampling methods (e.g., VSS or ISVS) and the analytical methods must ensure that the $30 \%$ uncertainty requirement is met. 


\subsection{DATA OPTIMIZATION}

This section specifies the number of samples required, the appropriate quality controls, and any unusual reporting requirements. The basis for the quality controls is the Hanford Analytical Services Quality Assurance Requirements Documents (DOE 1996). Appropriate implementing Quality Assurance Plans are prepared by each particular project as required. For each sample analysis, the laboratory shall follow the appropriate quality assurance requirements document (DOE 1996) for calibration, method blanks, and any additional quality control.

One set of headspace vapor samples, plus additional quality control samples as specified by the Quality Assurance Project Plan for Tank Vapor Characterization (Trible and Viswanath 1996), will be collected directly under an accessible riser for each waste tank sampled. Sufficient gas volume shall be collected to allow analysis for TNMOCs and semivolatiles (if necessary). The waste tank headspace temperature $\left({ }^{\circ} \mathrm{C}\right)$ will also be taken at the same time that the headspace measurements are obtained.

The quality control field duplicate and field blank will be collected for the waste tank in the same location as the original sample. The field blank will be collected and passed through the equipment prior to collecting the headspace sample from the waste tank to ensure that the equipment is clean before beginning the analysis. The associated measurement error will be determined and noted. 


\subsection{REFERENCES}

Cowley, W. L., and A. K. Postma, 1996, Analysis of Consequences of Postulated Solvent Fires an Hanford Site Waste Tanks, HNF-SD-WM-CN-032, Rev, 0A, Westinghouse Hanford Company, Richland, Washington.

Cowley, W. L., J. E. Meacham, J. M. Grigsby, and A. K. Postma, 1997, Organic Solvent Topical, WHC-SD-WM-SARR-036, Rev. 1A, Duke Engineering and Services Hanford, Richland, Washington.

DOE, 1996, Hanford Analytical Services Quality Assurance Requirements Documents (Vol 1-4), U.S. Department of Energy, Richland Operations Office, Richland, Washington.

EPA, 1988, Second Supplement to Compendium of Methods for the Determination of Toxic Organic Compounds in Ambient Air, EPA/600/4-89/018, U.S. Environmental Protection Agency, Washington, D.C.

Huckaby, J. L., J. A. Glissmeyer, and D. S. Sklarew, 1997, Screening for Organic Solvents in Hanford Waste Tanks Using Total Non-Methane Organic Compound Vapor Concentrations, PNNL-11490, Pacific Northwest National Laboratory, Richland, Washington.

Postma, A. K., and R. K. Hilliard, 1983, Hydrogen Generation, Distribution and Combustion Under Severe LWR Accident Conditions - A State of Technology Report, HEDL-TME-82-7, Westinghouse Hanford Company, Richland, Washington.

Trible, T. C., and R. S. Viswanath, 1996, Quality Assurance Project Plan for Tank Vapor Characterization, WHC-SD-WM-QAPP-013, Westinghouse Hanford Company, Richland, Washington.

Turner, D. A., H. Babad, L. L. Buckley, and J. E. Meacham, 1995, Data Quality Objective to Support Resolution of the Organic Complexant Safety Issue, WHC-SD-WM-DQO-006, Rev. 2, Westinghouse Hanford Company, Richland, Washington. 
HNF-SD-WM-DQO-026, Revision 0

This page intentionally left blank. 
APPENDLX A

TECHNICAL BASES FOR SURFACE AREA OF SOLVENT POOL 
HNF-SD-WM-DQO-026, Revision 0

This page intentionally left blank.

A-2 


\section{APPENDIX A \\ TECHNICAL BASES FOR SURFACE AREA OF SOLVENT POOL}

This appendix summarizes the organic solvent vapor model and combustion model.

\section{A.1 BACKGROUND}

A solvent fire hazard is most likely to exist for tanks containing waste from process waste streams that might have contained significant quantities of entrained solvents, and for which operating histories may have allowed the solvents to persist as a separate phase for many years. The methodology described in this appendix (Cowley and Postma 1996, Cowley et al. 1997) was developed for screening passively-ventilated waste tanks with respect to solvent pool fire risk. The methodology is based on the following postulates.

- The organic solvent pool surface area can be estimated from waste tank information, organic solvent parameters, and measured concentrations of organic vapors in the waste tank headspace.

- An organic solvent pool surface area can be defined on the basis of waste tank structural limits such that an organic solvent pool fire poses an acceptably small risk.

Recently obtained vapor characterization data have shown that hydrocarbon species initially present in solvents are present in waste tank headspaces. Vapor characterization data are used with an evaporation model to estimate the size of the solvent pool that feeds vapors into the waste tank headspace. A criterion has been derived such that possible organic solvent pools are sufficiently small so that the consequences of a postulated combustion are small enough not to challenge the tank structural limits. Hence, the risk from a small organic solvent combustion are within the risk evaluation guidelines.

\section{A.2 ESTIMATE OF POOL SURFACE AREA}

To determine the pool surface area in specific waste tanks, a simple solvent vapor transport model was developed (Cowley and Postma 1996, Cowley et al. 1997) by equating the vapor outflow rate in the ventilation air to the pool evaporation rate. In the resulting equation, the pool surface area is correlated with the concentration of solvent vapors in the waste tank headspace. Important parameters in the model are headspace ventilation rate, temperature at the pool surface, mass transfer coefficient for solvent evaporation, volatility of the solvent at a specified temperature, and concentration of solvent vapors in the waste tank headspace.

The following are key assumptions of the modeled waste configuration: 
- The waste tank headspace is passively ventilated by atmospheric pressure fluctuations and by instrument purge air.

- The waste tank headspace is well mixed by natural convection driven by the transport of decay heat across the headspace.

- An organic solvent pool exists on the waste surface or is submerged beneath the waste.

- Transport rates in waste are adequately modeled by one-dimensional models.

- Headspace characterization data, including temperature and concentration of solvent vapors, are available.

The following items provide a summary of the organic solvent vapor transport model.

- The steady state diffusion flux of organic vapors within a pore of constant cross section is represented as the flux caused by diffusion and the flux caused by the bulk flow of the total gas.

- A mass balance of solvent vapor in the waste tank headspace is used to relate headspace vapor concentration to the rate at which solvent vapors enter the headspace from the solvent pool.

- The mass concentration of solvent vapor in equilibrium with the liquid depends on the temperature and composition of the solvent liquid.

- The average heat flux in the upward direction is computed from the mean difference in temperatures between the tank headspace and the atmosphere.

- The mass transfer coefficient at the solvent/air interface is estimated by using a correlation of natural convective heat transfer coefficients where the convective heat transfer coefficient is expressed as a function of the temperature difference between the surface and bulk air.

The solvent vapor transport model then provides the bulk concentration of the solvent vapor in the headspace air in terms of the solvent vapor concentration in equilibrium at the liquid surface, the solvent pool surface area, the ventilation flow rate, and the mass transfer coefficient at the solvent/air interface. 


\section{A.3 THERMAL HYDRAULIC MODELING OF CONFINED SOLVENT POOL FIRES}

A combustion of fuel in the confined air volume of a waste tank would heat the air and cause an increase in internal pressure. The peak pressure that can develop from a solvent pool fire depends on how rapidly heat energy is evolved from the fire as compared to the rate at which energy can be dissipated through heat transfer to tank surfaces and by gas outflow through leak paths.

Internal gas pressure and temperature were computed as a function of time by performing energy and mass balances on the air inventory in the waste tank for relatively short ( 0.1 to 1 second) time steps. Conditions at the end of a time step were used as initial conditions for the next step. Numerical evaluations were accomplished by means of a simple computer program. Algorithms used to quantify important parameters in the energy and mass balances are described below.

- The gas phase (tank headspace) is treated as one node. Temperature and pressure are assumed to be uniform throughout the gas phase.

- Exposed concrete is treated as a one dimensional slab. Heat transfer to the slab is calculated at each time step. Transient heat conduction in the concrete is calculated in nodes of uniform area and thickness.

- Waste is also treated as a one-dimensional slab. The waste area is calculated by deducting the area of the solvent pool from the tank cross-sectional area.

- The steel lining of the cylindrical walls and steel internal structures (risers, thermocouple trees) are treated as a single node of specified area and mass. Heat transfer from the gas to the exposed side of the steel is calculated, but heat loss from the back side of the steel is neglected.

- A solvent pool of prescribed area and depth is treated as one node. Heat transfer from heated gas is accounted for, but heat loss to underlying waste is neglected. The inflamed area of the pool is calculated at each time step to account for radial spread of the flame.

- Gas venting is quantified by specifying an orifice of prescribed diameter and flow coefficient between the waste tank and the outside atmosphere.

- The rate of energy production by a solvent fire is computed as the product of the specific combustion energies (based on mass fractions of normal paraffin hydrocarbons and tributyl phosphate), inflamed area, and specific burning rate. 


\section{A.4 DEFINITION OF INSIGNIFICANT POOL AREA}

An insignificant solvent pool is defined as a solvent pool with small surface area such that if the solvent were to combust the resulting increase in internal tank pressure would not challenge the waste tank structural limits [for single-shell tanks (SSTs), the internal pressure limit is $11 \mathrm{psig}$.

A screening criterion is used to separate waste tanks that might contain significant amounts of organic solvent from waste tanks that may have an insignificant amount of solvent. A conservative estimate of the organic pool area that could lead to significant tank pressurization was obtained by analyzing a postulated fire in a SST which had minimal vent openings. Constraints used in the analysis included the following.

- The fire was initiated on a circle $1 \mathrm{ft}(0.3 \mathrm{~m})$ in diameter.

- The fire spread radially at a velocity of $10 \mathrm{~cm} / \mathrm{s}$.

- Vent paths were limited to the U-Tube seal on the HEPA vent riser.

- The duration of the fire was limited by oxygen extinguishment at $13 \% \mathrm{O}_{2}$.

- Peak pressure was limited to 5 psig, or roughly half the 11 psig capacity of the SSTs (see Cowley and Postma 1996).

Based on these constraints, the thermal hydraulic model concluded that combustion of organic solvent in any SST having an organic solvent pool area of $1 \mathrm{~m}^{2}$ or less would not result in exceeding tank structural limits with a safety factor of 2 . In fact, organic solvent pools of much larger area than $1 \mathrm{~m}^{2}$ did not result in risks that exceeded the risk evaluation guidelines. Thus, a $1 \mathrm{~m}^{2}$ area organic pool can be used as a very conservative screen to identify tanks that could pose an unacceptable fire risk.

\section{A.5 EQUIVALENT POOL SIZE RELATED TO ORGANIC VAPOR SAMPLES}

Based on the above analysis, a model is used to determine the saturated organic concentration in a waste tank headspace from a $1 \mathrm{~m}^{2}$ organic solvent pool as a function of the waste tank temperature, pressure, and ventilation rate. Vapor samples have been taken from over 65 waste tanks. The actual observed maximum organic vapor concentration for each waste tank, corrected for temperature and pressure as a function of the minimum waste tank headspace temperature, are graphed in Figure A-1 as the open circles. The waste tank conditions (temperature, pressure, and ventilation rate) for the observed organic vapor concentration were used with the model to calculate the headspace saturated organic concentration that would correspond to a $1 \mathrm{~m}^{2}$ organic solvent pool as a function of temperature. These corresponding model calculations that used actual waste tank conditions are graphed in Figure A-1 as the 
solid squares. Model calculations of the headspace saturated organic concentration that would correspond to a $1 \mathrm{~m}^{2}$ organic solvent pool as a function of temperature were also completed assuming a pressure of 1 atmosphere and a constant ventilation rate of $2 \mathrm{~m}^{3} / \mathrm{hr}$. These model calculations are shown in Figure A-1 as the solid line.

Figure A-1. Comparison of Waste Tank Sample Data with the Model Calculation for a $1 \mathrm{~m}^{2}$ Puddle Assuming $1 \mathrm{~atm}$ Pressure and $2 \mathrm{~m}^{3} / \mathrm{hr}$ Ventilation.

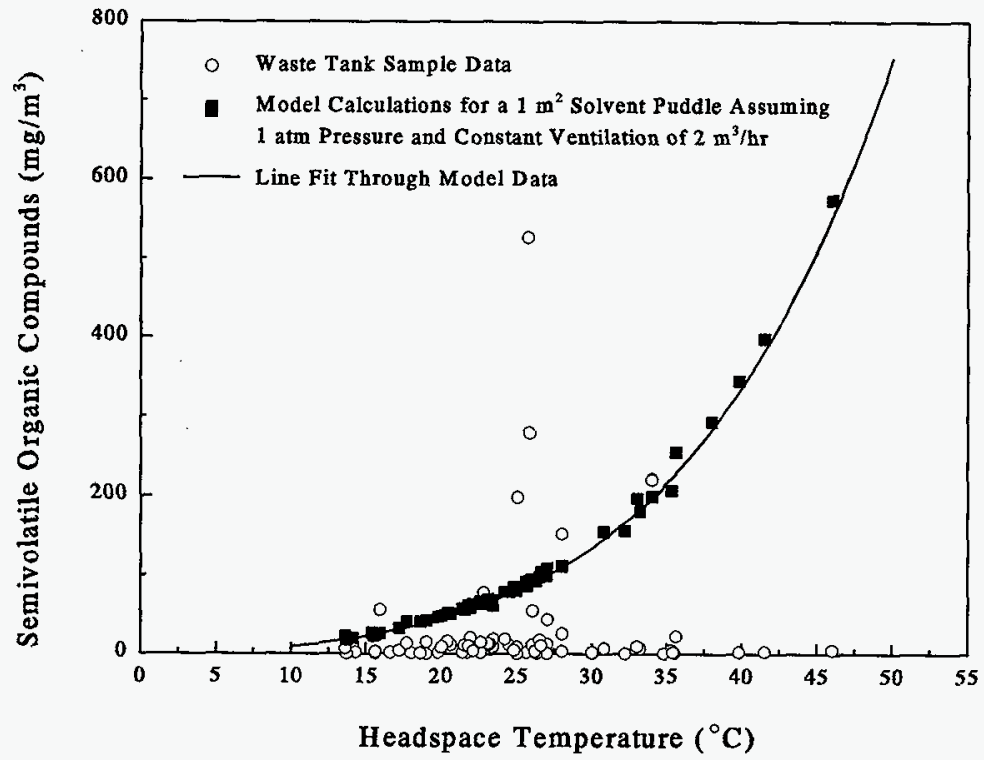

As seen in Figure A-1 there is reasonable agreement between the calculated saturated organic concentration using the actual waste tank pressure and ventilation rate (solid squares) and the calculated saturated organic concentration assuming a pressure of 1 atmosphere and a constant ventilation rate (solid line). In the calculations of Figure A-1 the actual waste tank ventilation rate was estimated from the waste tank breathing rate.

Note in Figure A-1 there are seven waste tanks for which the measured saturated organic concentration in the headspace is larger than the calculated saturated organic concentration expected from a $1 \mathrm{~m}^{2}$ organic solvent pool. The analysis would suggest that these seven waste tanks have a total surface area of organic liquid that is greater than $1 \mathrm{~m}^{2}$. However, the 
analysis also suggests that even these seven waste tanks would not exceed the risk evaluation guidelines.

The solid line in Figure A-1 can be used as a criterion for the headspace saturated organic concentration expected from a $1 \mathrm{~m}^{2}$ organic solvent pool. This criterion is presented in Figure A-2. The criterion graphed in Figure A-2 is listed in Table A-1 for convenience.

As more waste tank vapor sample data are obtained and analyzed, and the model and analysis are refined, the criterion may also need to be refined. This is particularly true as better information on waste tank ventilation rates becomes available.

Application of the $1 \mathrm{~m}^{2}$ organic solvent pool as a preliminary screen to identify waste tanks that could pose an unacceptable fire risk is as follows. The waste tank headspace is sampled for total non-methane organic compounds (TNMOCs) using the Environmental Protection Agency (EPA) TO 12 or modified TO 12 methods. The temperature of the headspace is also measured. The measured saturated organic concentration (measured under dry conditions at standard temperature and pressure) in the waste tank headspace as a function of the waste tank headspace temperature is compared to the expected saturated organic concentration in the waste tank headspace from a $1 \mathrm{~m}^{2}$ organic solvent pool, using Figure A-2, or Table A-1. If the measured organic vapor concentration at the appropriate headspace temperature is below the criterion curve in Figure A-2 or Table A-1, then any organic solvent pool on the waste surface is judged to have an area that is less than $1 \mathrm{~m}^{2}$, and any resulting increase in internal waste tank pressure from organic solvent combustion would not exceed the waste tank structural limits. Consequently, the risk from the combustion of such an organic solvent pool would be low.

On the other hand, if the measured organic vapor concentration at the headspace temperature is above the criterion curve in Figure A-2 or Table A-1, then the organic solvent pool on the waste surface is judged to have an area that may be greater than $1 \mathrm{~m}^{2}$, and the resulting increase in internal waste tank pressure from organic solvent combustion may exceed the waste tank structural limits. This waste tank would require further evaluation to determine if the risk associated with organic solvent combustion would exceed the risk evaluation guidelines. 
Figure A-2. Criterion of the Waste Organic Vapor Concentration as a Function of the Headspace Temperature.

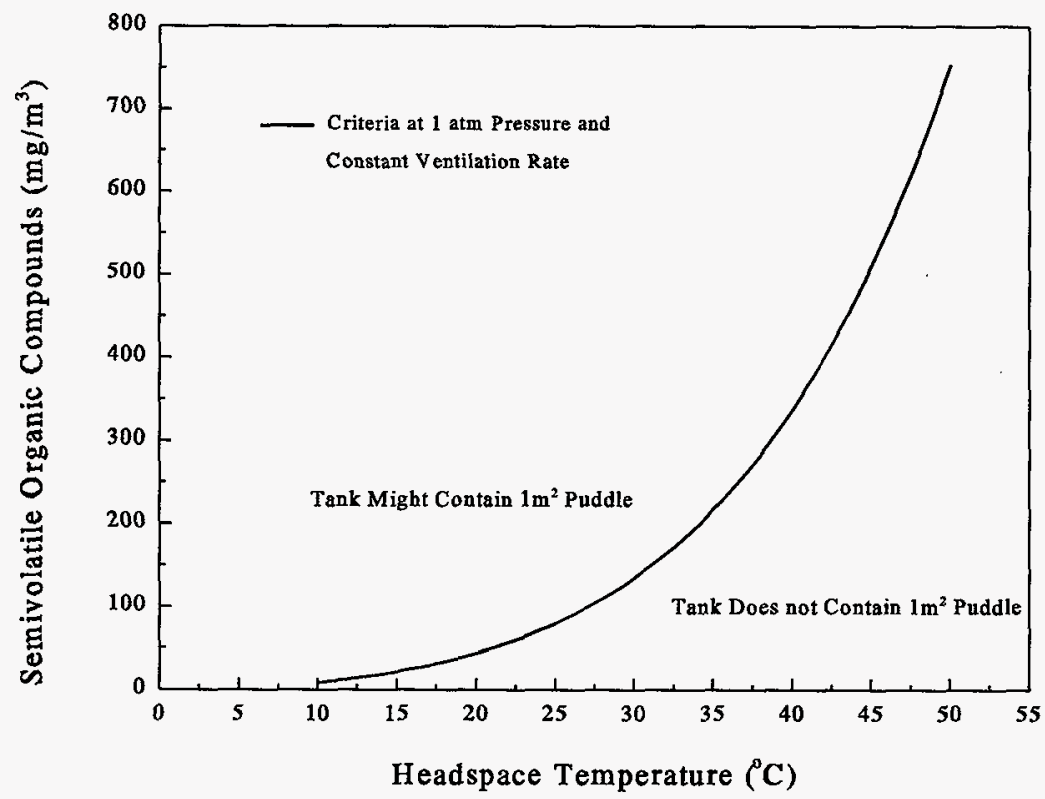

As an example, a measured organic vapor concentration of $125 \mathrm{mg} / \mathrm{m}^{3}$ at a headspace temperature of $25^{\circ} \mathrm{C}$ would be unacceptable as a preliminary safety screen. On the other hand, a measured organic vapor concentration of $30 \mathrm{mg} / \mathrm{m}^{3}$ at a headspace temperature of $25{ }^{\circ} \mathrm{C}$ would be acceptable. Or, referring to Table A-1, at a headspace temperature of $25^{\circ} \mathrm{C}$ a measured organic vapor concentration less than $80 \mathrm{mg} / \mathrm{m}^{3}$ would be acceptable, while a measured organic vapor concentration greater than $80 \mathrm{mg} / \mathrm{m}^{3}$ would be unacceptable. 
Table A-1. Waste Tank Organic Vapor Concentration as a Function of the Headspace Temperature at $1 \mathrm{~atm}$ Pressure and Ventilation Rate of $2 \mathrm{~m}^{3} / \mathrm{hr}$.

\begin{tabular}{|c|c|c|c|}
\hline $\begin{array}{c}\text { Temperature } \\
\left({ }^{\circ} \mathrm{C}\right)\end{array}$ & $\begin{array}{c}\text { Measured Saturated Organic } \\
\text { Concentration Less Than } \\
\left(\mathrm{mg} / \mathrm{m}^{3}\right)\end{array}$ & $\begin{array}{c}\text { Temperature } \\
\left({ }^{\circ} \mathrm{C}\right)\end{array}$ & $\begin{array}{c}\text { Measured Saturated } \\
\text { Organic Concentration Less } \\
\text { Than }\left(\mathrm{mg} / \mathrm{m}^{3}\right) \\
\end{array}$ \\
\hline 10 & 9 & 31 & 149 \\
\hline 11 & 11 & 32 & 164 \\
\hline 12 & 14 & 33 & 181 \\
\hline 13 & 16 & 34 & 198 \\
\hline 14 & 19 & 35 & 217 \\
\hline 15 & 22 & 36 & 238 \\
\hline 16 & 26 & 37 & 261 \\
\hline 17 & 30 & 38 & 285 \\
\hline 18 & 34 & 39 & 310 \\
\hline 19 & 39 & 40 & 338 \\
\hline 20 & 45 & 41 & 368 \\
\hline 21 & 50 & 42 & 400 \\
\hline 22 & 57 & 43 & 435 \\
\hline 23 & 64 & 44 & 472 \\
\hline 24 & 72 & 45 & 511 \\
\hline 25 & 80 & 46 & 554 \\
\hline 26 & 89 & 47 & 599 \\
\hline 27 & 99 & 48 & 648 \\
\hline 28 & 110 & 49 & 699 \\
\hline 29 & 122 & 50 & 754 \\
\hline 30 & 135 & & \\
\hline
\end{tabular}

\section{REFERENCES}

Cowley, W. L., and A. K. Postma, 1996, Analysis of Consequences of Postulated Solvent Fires an Hanford Site Waste Tanks, WHC-SD-WM-CN-032, Rev. 0A, Westinghouse Hanford Company, Richland, Washington.

Cowley, W. L., J. E. Meacham, J. M. Grigsby, and A. K. Postma, 1997, Organic Solvent Topical, HNF-SD-WM-SARR-036, Rev. 1A, Duke Engineering and Services Hanford, Richland, Washington. 


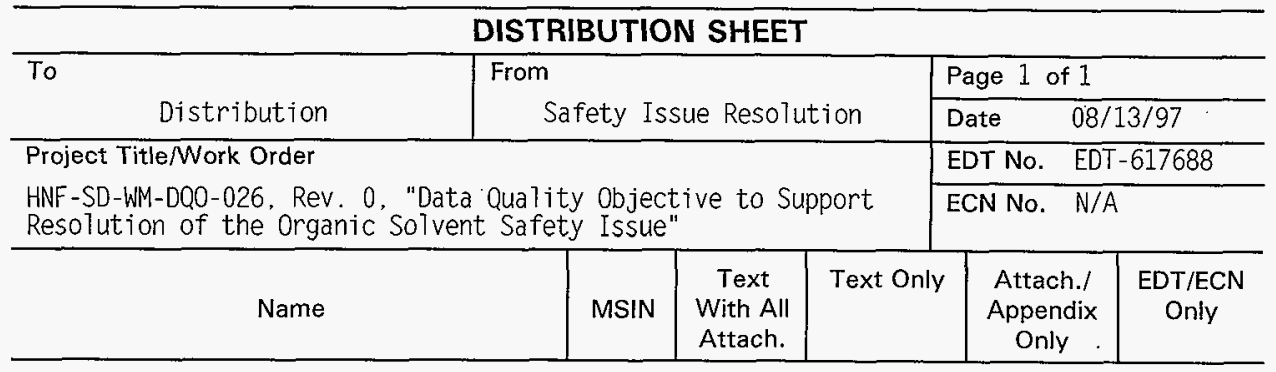

ONSITE

U.S. Department of Energy - Richland Operations Office

S. 0 . Branch

W. F. Hendrickson

D. H. Irby

C. L. Sohn

Public Reading Room

RL Docket File

$57-54 \quad 2$

$57-54 \quad x$

S7-54 $\quad x$

S7-5. $\quad x$

$\mathrm{H} 2-53 \quad X$

B1-17 2

DE\&S Hanford. Inc.

R. J. Cash

W. L. Cowley

J. E. Meacham

S7-14

R1-49

S7-14

Lockheed Martin Hanford, Corp.

O. L. Banning

N. W. Kirch

R2-12 X

R2-11 $\quad X$

D. J. McCain

R2-12 $\quad x$

T. C. Trible

S7-07

T.C.S.R.C.

R1-10

$x$
$x$
$x$

Lockheed Martin Services. Inc.

Centra] Files

Correspondence Processing

Pacific Northwest National Laboratory

R. T. HaTlen

J. L. Huckaby
A3-88

A3-01

$x$

K2-12

K6-80

2
$x$
$x$
$x$
$x$
2

x

